4) подчиненный верит, что его усилия не будут напрасными и их справедливо оценит руководство [6].

Таким образом, могут быть рекомендованы методы убеждения и участия, которые действуют хоть медленно, но определенно. При использовании данных методов, увеличивается эффективность управления, когда подчиненным предлагают удовлетворение потребностей более высокого уровня, особенно в том случае, если работа требует творческих затрат.

\title{
Литература
}

1. Богатырева, О.О. Проблема профессиональной самореализации: социально- психологический и культурно-исторический аспект [Текст] / О.О. Богатырева // Мир психологии - 2009. - № 1 - 87 с.

2. Богатырева, О.О. Психологические предпосылки карьерного роста [Текст] / О.О. Богатырева // Вопросы психологии - 2008. - № 3. - 58 с.

3. Демократический стиль управления [Электронный ресурс]. 2014. Режим доступа: http://brandenso.com/democratic-style-of-management (дата обращения 15 мая 2014 года)

4. Наставнический стиль. Эффективное лидерство [Электронный ресурс]. 2006. Режим доступа: http:/gtmarket.ru/laboratory/expertize/2006/463 (дата обращения 1.01.2017 года).

5. Пантелеев, С.Р. Методы измерения локуса контроля [Текст] / С. Р. Пантелеев // Под ред.А. А. Бодалева, В.В. Столина. - М.: МГУ, 2007. - 163 с.

6. Стили управления [Электронный ресурс]. 2014. Режим доступа: http:// www.strategplann.ru/maloe-predprijatie/stili-upravlenija.html (дата обращения 1.01.2017 года).

7. Чикер, В. А. Психологическая диагностика организации и персонала [Текст] / В. А. Чикер. - М.: Речь, 2004. - 257 с.

8. Шейн, Э. Организационная культура и лидерство [Текст] / Э. Шейн. СПб.: Питер, 2008. - 199 с.

\section{ПРИМЕНЕНИЕ БЕЗИНСТРУМЕНТАЛЬНЫХ МЕТОДИК ДЕТЕКЦИИ ЛЖИ В ПРОФЕССИОНАЛЬНОЙ ДЕЯТЕЛЬНОСТИ ПСИХОЛОГА НА ПРЕДПРИЯТИИ}

\section{Иванова Н.Б. Научный руководитель: к.псх.н., доцент Макаревская Ю.Э.}

В современных условиях возрастающих требований к профессиональным и личностным качествам специалистов на предприятиях, наиболее актуальным становится вопрос тщательного отбора кандидатов. Один из главных факторов, определяющий устойчивый процесс деятельности, стабильность и конкурентоспособность любой организации - ее безопасность и эффективность деятельности субъекта труда. В каждой организации, в зависимости от сферы деятельности, предъявляются особые требования к сотрудникам. Профессиональная надежность человека определяется его работоспособностью, выносливостью к напряжению и перенапряжению, особенностями эмоциональных реакций, темпом и точностью усвоения необходимых навыков, 
характером поведения в экстремальных и стрессовых ситуациях [4]. «В сложной структуре характерологических свойств основными являются параллельно развивающиеся и взаимовлияющие друг на друга такие подструктуры, как эмоции, мотивация, особенности интеллектуальной сферы и стиль межличностного поведения» [6, с. 8$]$.

Как правило, разработка процедуры профессионального психологического отбора состоит из нескольких этапов. На профессиографическом, осуществляется изучение, анализ и систематическое описание профессиональной деятельности. Результатами этого анализа являются: профессиограмма - комплексное описание профессиональной деятельности и психограмма - список психологических профессионально важных качеств работника, влияющих на его эффективность в процессе достижения профессионально значимого результата. Важным этапом является формулировка критериев, которые будут использоваться при создании программ адаптации, обучения и развития сотрудников организации.

На технологическом этапе осуществляется разработка технологии психологического обследования: подбираются методики, составляется «тестовая батарея», вырабатывается алгоритм анализа и интерпретации результатов, разрабатываются форма и структура представления результатов.

Для комплексной психодиагностики, для разностороннего исследования личности, темперамента, коммуникативных компетенций, физиологических возможностей, особенностей реагирования в ситуации стресса применяются надёжные и валидные методики, как аппаратурные, с применением электронной и компьютерной техники, так и обычное анкетирование, интервью, беседа.

Как показывает практика, что при успешном прохождении тестирования, где выявлены предпочтительные и желательные качества обследуемого предъявляемые к сотрудникам предприятия и кандидатам на вакансии, для психолога всегда остро встаёт вопрос, насколько откровенен в ответах был респондент, если человек, желая получить работу, лгал, искажал информацию, умалчивал, недоговаривал, то результаты тестов являются недостоверными и вся информация о данном субъекте оказывается ничтожной. «Учитывая характер требования вербальных методик, следует всегда помнить о том, что они могут спровоцировать у испытуемого достаточно изощренную защитную реакцию на процедуру обследования» [6, с. 111]. Если личностные качества кандидата на вакансию не будут соответствовать требованиям данной должности, цена ошибки будет очень велика для предприятия. В связи с этим, для успешного решения кадровых задач психологу требуются знания в области психологии лжи.

Психология понимания и распознавания лжи, лживости и скрываемой информации, много лет разрабатываемая в западной психологии, для российской науки является относительно новой и мало изученной областью исследований. Основой исследований социально-психологических особенностей лжи явились фундаментальные и прикладные психологические теории, концепции, положения и разработки: 
Теоретические положения психологии лжи и скрываемой информации: В.В.Волкова; В.В. Знакова; И.А.Ильина; И.Канта; Я.С.Кротова; А.Н.Тарасова; Л.Б.Филонова; О.Фрая; Ю.Щербатых; П.Экмана. Теории мотивации и мотивов поведения: В.Г. Асеева; В.К. Вилюнаса; В.Г. Выготского; Е.П.Ильина; А. Маслоу; П.В.Симонова; Д.И.Узнадзе; П.М.Якобсона. Идеи и взгляды, представленные в научных трудах: А.В.Фесенко; О.Фрая; Ю.И.Холодного; И.А.Церковной; Н.Гордона; В.В.Коровина и Л.Г.Алексеева.

В настоящее время исследование проблемы сокрытия информации и лжи является одной из наиболее актуальных не только для правоохранительных структур, органов безопасности, но и кадровых служб предприятий. Для осуществления мероприятий профессионального отбора и рационального распределения кадров, прогнозирования поведения людей, а также для выявления потенциально нежелательных сотрудников актуальными становятся методики инструментальной и безынструментальной детекции лжи, кадровый профайлинг.

Современному психологу в организации необходимо обладать знаниями в области верификации и профайлинга. Верификатор - специалист, подтверждающий соответствие сообщаемых сведений критериям истинности. В своей практике верификатор использует все техники как безынструментальной, так и инструментальной детекции лжи для вынесения суждения о правдивости или ложности высказывания. В большинстве случаев верификатора интересует информация о прошлом и настоящем. Если рассматривать безынструментальную детекцию лжи, то снизить вероятность попадания неблагонадежных кандидатов в организацию позволяет применение технологий профайлинга. Профайлинг используется более широко. Несмотря на то, что данное направление относительно молодое в практике применения его в России, оно становится всё более востребованным.

Профайлер - специалист, использующий совокупность психологических методов и методик оценки и прогнозирования поведения человека на основе анализа наиболее информативных частных признаков, характеристик внешности, а также вербального и невербального поведения.

В рамках использования инструментов кадрового профайлинга при проведении исследования респондента, анализу подлежит:

- Метапрограммный профиль, лингвистический и поведенческий, - это набор бессознательных фильтров восприятия человека, основа на которой формируются основные жизненные и поведенческие стратегии и убеждения. Знания о метапрограммном профиле позволят выяснить эффективность кандидата и соответствие должности, на которую претендует; понять, с помощью каких способов он воспринимает информацию; выявить профессиональные возможности и ограничения каждого конкретного кандидата; каким образом мотивируется человек; способ и основания для принятия решений; понять, прогноз взаимодействия с членами коллектива.

Метапрограммы обычно рассматриваются парами, которые представляют собой два противоположных подхода к решению определенной задачи. Один из возможных признаков лжи говорящего - это переход из одного 
метапрограммного профиля в другой. Метапрограммы - это базовые фильтры восприятия человека. Они отвечают за то, как мы воспринимаем информацию и выходят за рамки нашего сознательного мышления, управляют ним. Например, метапрограмма “Тип связи” определяет, ищем ли мы в воспринятой информации тождество с уже имеющимся опытом или различия. Или метапрограмма “Тип репрезентативной системы” главный канал восприятия информации: визуальный, аудиальный, кинестетический или аудиальнодигитальный. То есть кинестетик будет ориентироваться на чувства и воспринимать информацию посредством ощущений.

- Характерологические особенности на основании базового психотипа группы однородных качеств и стереотипов поведения, сила и подвижность нервной системы, особенности эмоциональной и интеллектуальной сферы человека. Данная информация позволит выяснить слабые и сильные стороны кандидата; выяснить факторы риска; спрогнозировать поведение кандидата в различных ситуациях; условия адаптации и дезадаптации кандидата, вид максимально эффективной/неэффективной деятельности

- Карта мотиваторов - приоритетность мотивов и мотиваторов при поступлении на данную должность кандидата.

Отслеживаются реакции, изменений:

- Тела: позы и центра тяжести, жестов, зажимов, движений ногами, туловищем, головой и шеей, а также темп всех этих движений.

- Лица: мимики, движений глаз, эмоций, цвета лица.

- Голоса: темпа речи, интонации, пауз, громкости, тембра.

- Дыхания: глубины, темпа.

- Речи: что говорит, какие слова использует.

Признаки вегетативной нервной системы (BНC) всегда были очень информативными, именно на них опирались первые модели детекции лжи и первые полиграфы. Регистрировать подобные сигналы может и специалистпрофайлер, это возможно, если выделить и описать основные маркеры лжи по признакам ВНС: бледность кожных покровов в состоянии стресса, уменьшение слюнного секрета (сухость во рту) связано с тем, что в ситуации стресса силы организма направлены на сопротивление, угнетаются все системы пищеварения, изменения голосовых модуляций, тона голоса также может свидетельствовать о наличии скрываемой информации, лжеца выдает дыхание, различными сбоями, рваным ритмом. Важным источником информации о правдивости или ложности высказывания является речь, которая изобилует увертками и другими нейролингвистическими признаками обмана.

А. Мейерабиан установил, что передача информации происходит:

- за счет вербальных средств (только слов) на 7 \%,

- за счет звуковых средств (включая тон голоса, интонацию звука) на 38\%,

- за счет невербальных средств на 55\%.

Невербальное поведение с учетом трудностей его контролирования является самым ценным источником информации при выявлении лжи говорящего. 
Конгруэнтное поведение, выражающее внутренние состояния и стремления, это заметно со стороны по невербальным проявлениям: согласованности слов и действий с мимикой (микровыражения лица), жестами, интонацией и тембром голоса, гармоничности движений и их адекватности ситуации. Сеченов утверждал, что каждая мысль имеет мускульное проявление. Таким образом, мышление и движение мышц взаимосвязаны.

Также, в профайлинге используется метод особого построения вопросов для определения лжи: начиная беседу в комфортной атмосфере в стиле, отвечающему базовому психотипу (создания доверия, сближения с человеком, глубокой подстройки), далее переходя на темы, непосредственно связанные с диагностикой лжи, создавая вербальные и невербальные провокации, то есть стимулы, уточняющие вопросы, углубление стрессовых тем. При разговоре на некомфортные темы может появиться стресс. Отслеживая реакции человека, важно увидеть точку ориентировочного замирания (ТО3) - это первая реакция на стресс, характеризуется замиранием/паузой между словами. Также, как ответная реакция на стресс, возрастает количество адаптеров (жесты, которые позволяют нам адаптироваться к стрессу), их основная задача - адаптировать тело в стрессовой ситуации, и возрастает количество манипуляторов (жесты прикосновений к одежде и предметам), уменьшается количество иллюстраторов (жесты, подкрепляющие сообщение). Также, возможна смена метапрограммного профиля.

Верный признак лжи - эмблематическая оговорка (это те жесты, которые заменяют слова, их всегда показывают намеренно. Примером эмблем может быт пожимание плечами, что значит “не знаю”, или покачивание головой в стороны, означающее “нет”. Так же как случаются оговорки в речи, бывают промахи и в телодвижениях - это и есть эмблематические оговорки, выдающие информацию, которую человек пытается скрыть.

В ситуации стресса, когда человек лжёт, провоцируются реакции лимбической системы (представляет собой функциональное объединение структур мозга, участвующих в организации эмоционально-мотивационного поведения, таких как пищевой, половой, оборонительный инстинкты): реакция стой (это первая реакция на стресс, человек сразу после получения стрессового стимула замирает (ТО3). После этого человек решает атаковать или бежать от стимула, врать или говорить правду), реакция бей (проявляется в агрессивности, психологической атакой на соперника, ответом вопросом на вопрос, внешние признаки напряженности), реакция беги (проявляется в физическом - отстройка и увеличение дистанции с собеседником и речевом дистанцировании.

Отслеживая все вышеуказанные реакции организма и изменения в поведении человека при психологическом тестировании, проведении собеседования, психолог с большой долей вероятности может распознать насколько правдивую информацию предоставляет кандидат на вакансию или сотрудник организации, соответственно сделать выводы о достоверности результатов тестов и свести минимуму возможность ошибки при принятии 
решения о соответствии/несоответствии кандидата или сотрудника определённой должности.

Суть личностного и социального профайлинга состоит из определенных поведенческих стратегий, которые человек использует при решении любых задач в различных ситуациях. Понимание этих поведенческих стереотипов и анализ задач, которые решаются человеком в конкретный период времени позволяет делать достаточно точный прогноз поведения человека или группы людей. Использование профайлинга показало высокую эффективность его применения в решении проблем жизнедеятельности человека, коммуникации, профессионального отбора, в раскрытии и профилактике преступлений.

В связи с этим, существует востребованность, широкое распространение и развитие моделей и методов данного направления у нас в стране и за рубежом. Для того, чтобы быть профессионалом в безынструментальной детекции лжи, необходимы не только глубокие теоретические знания, но и большой практический опыт. «Психологическое исследование всегда было и останется в известной степени искусством, а методика - всего лишь инструмент, который только в умелых руках способствует раскрытию образа личности» [6, с. 111].

\section{Литература}

1.Душков, Б. А. Психология труда, профессиональной, информационной и организационной деятельности / Б. А. Душков, А.В. Королев, Б. А. Смирнов. Москва: Фонд «Мир», 2005- 846с.

2.Залевский Г.В. Личность и фиксированные формы поведения. - М.: Институт психологии РАН, 2007.

3.Занковский А.Н. Организационная психология: Учебное пособие для вузов по специальности «Организационная психология». - 2-е изд. - М.: Флинта: МПСИ 2002.-648 с.

4.Иванова, Е.М. Психология профессиональной деятельности /Е.М.Иванова. - М.: «PerSe», 2006. - 382 с.

5.Самоукина Н.В. Психология профессиональной деятельности. 2-е изд. СПб.: Питер, 2004. — 224 с. (Серия «Учебное пособие»).

6.Собчик Л.Н. Стандартизированный многофакторный метод исследования личности СМИЛ. С.-Пб. Изд. Речь, 2002.

7.Спирица Е.В. Психология лжи и обмана. Как разоблачить лжеца - СПб: «Питер» 2016.-272c.

8.Спирица Е.В. Вижу вас насквозь. Как "читать" людей - СПб: «Питер» 2017. - 192 с.

9.Шейнис М.Ю. Рабочая книга психолога организации. - Самара: Издательский дом «Бахрах-М», 2001. - 224 с, с. 84.

10. Управление персоналом: Учебник для вузов / Под ред. Т.Ю. Базарова, Б.Л. Еремина. — 2-е изд., перераб. и доп. - М: ЮНИТИ, 2002. — 560 с. 